\section{Gederi}

\section{SEDERI Yearbook}

ISSN: $1135-7789$

sederiyearbook@yahoo.es

Spanish and Portuguese Society for English

Renaissance Studies

España

Pujante, Ángel-Luis

The French Influence on Early Shakespeare Reception in Spain: Three Cases of Unacknowledged

Sources

SEDERI Yearbook, núm. 20, 2010, pp. 103-119

Spanish and Portuguese Society for English Renaissance Studies

Valladolid, España

Available in: http://www.redalyc.org/articulo.oa?id=333527607005

How to cite

Complete issue

More information about this article

Journal's homepage in redalyc.org

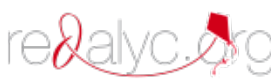

Scientific Information System Network of Scientific Journals from Latin America, the Caribbean, Spain and Portugal Non-profit academic project, developed under the open access initiative 


\title{
The French Influence on Early Shakespeare Reception in Spain: Three Cases of Unacknowledged Sources
}

\author{
Ángel-Luis Pujante \\ Universidad de Murcia
}

\begin{abstract}
Shakespeare criticism in Spain began in 1764 and has been on the increase ever since. The main source of information on the subject has long been the tremendous work done by Alfonso Par from the beginning of the 2oth century until his death in 1936: without his Shakespeare en la literatura española (1935) none of the later studies could have been written, or at least they would have taken a good deal longer to write. On the other hand, Par's book includes gaps and errors which need to be corrected. Among these are three cases of supposedly original texts which have turned out to be appropriations of foreign originals whose sources were not acknowledged. This article sets out to analyze these cases, examine their critical implications and thus contribute to a better knowledge and understanding of the Spanish reception of Shakespeare.
\end{abstract}

KEYWORDS: Shakespeare, Shakespeare criticism, Shakespeare reception, literary history, comparative literature.

I Shakespeare came to Spain in the $18^{\text {th }}$ century, not directly from England, but via France. He arrived as the monster created by

\footnotetext{
* This paper is part of Research Project FFI2008-01969/FILO, funded by the Spanish Ministry of Science and Innovation. The unacknowledged sources dealt with in this article were spotted in the course of the research carried out both for this project and for the previous one on the same subject ("The presence of Shakespeare in Spain in the framework of his European reception", HUM-2005-02556/FILO). I am particularly grateful to Michèle Willems for drawing my attention to the "Parallèle entre Shakespear \& Corneille," not mentioned in Jusserand (1889) or Pemble (2005).
} 


\section{A. L. Pujante}

Voltaire, bringing with it the controversy about his vices and virtues. The first Spanish critical text dealing with Shakespeare (1764), that of Mariano Nifo, involves the French neoclassical view of him and contains Voltaire's opinion of the French conception of tragedy as opposed to the English concept. From Nifo onwards and for several decades, most Spanish writers on Shakespeare joined the debate and took sides, the neo-classicists being critical of him, and the traditionalists (supporters of Lope de Vega and Calderón), in favour of him.

Critical interest in Shakespeare reception in Spain began with Daniel López's "Shakespeare en España" (1883), which contained a plentiful list of productions of Shakespearean adaptations between 1772 and 1838 and reflected the various responses to neoclassical adaptations, with particular attention to the translations used and the taste of the audiences. Going beyond performance, more wideranging studies followed, those of Eduardo Juliá (1918) and Ricardo Ruppert (1920), and, above all, the long and patient work of Alfonso Par, which culminated in his Shakespeare en la literatura española (1935). It is surprising that this Catalan businessman should have had such an interest in Shakespeare as to devote himself so wholeheartedly to his Spanish reception, spending three decades gathering such a huge amount of information, some of which was then rather hard to come by. Later students of the subject are therefore indebted to this extensive documentation which has made the continuation of his efforts an easier task. In fact, Shakespeare reception in Spain both in general and in its early manifestations, has been taken up forcefully since around 1990, as shown in a large number of relevant publications. ${ }^{1}$

However, Par's book includes a number of gaps and errors which need to be corrected. Here I shall focus on three critical texts considered by Par to be Spanish original articles but which have turned out to be translations of foreign texts whose source and authorship are not acknowledged by the authors of the three articles. One of them presents all the characteristics of plagiarism, as expressed in the definition given in the OED: "The wrongful

\footnotetext{
${ }^{1}$ For the early reception, see among others Calvo (2002, 2006, 2008); Deacon (1996); Gregor (2002, 2003, 2010); Kerson (1989a, 1989b); López Román (1988, 1989, 1993); Moro (1996); Pujante (1999, 2001a, 2001b, 2005, 2006, 2008); Pujante \& Campillo (2007); Pujante \& Gregor $(2005,2008)$; Verdaguer (2004).
} 
appropriation or purloining, and publication as one's own, of the ideas, or expression of the ideas (literary, artistic, musical, mechanical, etc.) of another." The other two cases may be different, but if they cannot be accused of wrongful appropriation, their wrongful uses are obvious. I shall deal with the three independently, though for the sake of methodological convenience a strictly chronological order will not be followed. At the same time, and in order to avoid misunderstandings, let it be stated from the outset that judicial accusation or judgement is not the purpose of the article, and that Par could only be held responsible for the errors and omissions in dealing with these three cases.

2 Discussing Spanish critical texts written in praise of Shakespeare at the beginning of the 19th century, Alfonso Par (1935:154-156) mentions an article by one G. Romo entitled "Paralelo entre Shakespeare y Corneille," published in a 1806 issue of Memorial Literario. In it, the author compares Shakespeare and Corneille without neoclassical prejudice and declares Shakespeare's superiority over the French playwright. For Par, this is "the first Spanish voice since Cadalso which rises with determination to elevate the British dramatist." ${ }^{2}$

However, Par did not know or suspect that the Romo article was in fact a translation of "Parallèle entre Shakespear \& Corneille," published anonymously in the Journal Encyclopédique in October 1760. The preference for Shakespeare over Corneille in France at that time can be accounted for by the rampant French Anglomania, which, according to J.J. Jusserand (1899:274), was also responsible for other similar writings in which Shakespeare was preferred to Corneille. Besides being an anonymous publication, this "parallèle" was not presented as an original contribution but as "traduit de l'Anglois." This can be explained by the fact that this French Anglomania had not displaced Neoclassicism, still very much alive in France, so one can understand that the author decided to pass off his article as "translated from the English" in an attempt to exempt

\footnotetext{
2 "La primera voz española que desde Cadalso se alza decidida para encumbrar al dramaturgo británico" (Par 1935:154). All the translations from the Spanish and French are my own.
} 


\section{A. L. Pujante}

himself (and any other French writer) from expected adverse neoclassical reactions.

Be that as it may, Romo appropriated the French article by translating it almost word for word and publishing it as his own with a few personal alterations. The following parallel quotations will suffice to show the extent of the appropriation -with Romo's additions emphasized in italics.

French original

Shakespear \& Corneille sont les deux plus grands génies que le Théatre Anglois \& le Théatre François ayent jamais eus. Il se trouve entre ces deux grands Poëtes des traites de ressemblance qui sont frappans. Corneille été le Pere de la Poësie dramatique en France; Shakespear en Angleterre. [...] Mais toutes les Tragédies de Shakespear roulant sur des sujets tout-à-fait différens les uns des autres, il n'est pas possible de trouver la moindre ressemblance entre les plans de Kinglear, de Hamlet, d'Othello, de Jules César, \& de Romeo. L'infortune de Kinglear est fondé sur les malheurs d'un pere; celle de Hamlet sur ceux d'un fils; celle d'Othello sur ceux d'un mari jaloux. [...] En un mot, on diroit que Shakespear a trop de génie pour s'assujetir aux régles du théâtre, \& que Corneille, s'il eut été un gran génie, $s^{\prime} y$ seroit moins asservi. [...]

\section{Romo's text}

Guillelmo Shakespeare y Pedro Corneille son los dos mayores ingenios que han producido los teatros ingles y frances. En los dos notamos acciones tan parecidas, y al mismo tiempo tan opuestas que verdaderamente causan admiración. Corneille ha sido el padre ó creador de la poesía dramática en Francia: Shakespeare lo ha sido igualmente en Inglaterra. No así las tragedias de Shakespeare; todas giran sobre objetos diferentísimos unos de otros; y así no es posible hallar la menor semejanza entre los planes del Rey Lear, de Hamlet, de Otelo, de Julio Cesar y de Romeo. La catástrofe del Rey Lear se funda sobre las desgracias de un padre, la de Hamlet sobre las de un hijo, la de Otelo sobre las de un marido celoso. En una palabra, diremos con uno de nuestros mejores literatos que Shakespeare tenía demasiado ingenio para sujetarse á las reglas del teatro, y que Corneille se hubiera sujetado aún menos si hubiera tenido mayor ingenio.

Romo effected various changes. He omitted a sentence in the original where Shakespeare is called "the mirror of Nature," replaced the last paragraph, in which new parallels are announced, 
with another in which Romo informs the reader of new, forthcoming parallels, and added four informative footnotes that were not in the French article. As for his addition at the end of the above quotation, to the effect that one of "our best writers" holds the opinion that Shakespeare was too much of a genius to subject himself to rules, Romo refers to Moratín in a footnote, and particularly to what he wrote in the prologue and "Life of Shakespeare" preceding his translation of Hamlet (1798). However, this is not what Moratín wrote. On the contrary, he was a staunch neoclassicist who kept proclaiming the need for the rules till the end of his life. After seeing Julius Caesar performed in London, he jotted down: "such an irregular play, dictated only by genius and without the aid which art can lend." ${ }^{3}$ And in "Life of Shakespeare" referred to by Romo, what he actually wrote was:

Such plays, even if they contain excellent fragments, will only help to perpetuate the corruption of taste and, if we end up admitting the maxim that a genius should not submit to scientific precepts and that it is not lawful to examine those great men, disciples of nature, fertile and uneducated as the original they imitated, there is no way: this opinion, once established, will be the ruin of the arts. ${ }^{4}$

As Par makes clear (1935:1.155), the Spanish article was severely challenged in the same Memorial Literario a month later in the article "Reflexiones acerca del paralelo entre Shakespeare y Corneille [...]," by one "J.S.C.", who, after praising Corneille, violently attacked Shakespeare. Clearly, J.S.C. did not know that the "Paralelo" was actually the Spanish rendering of a 1760 French original -with all that this implied, as will be discussed later- and assumed that Romo himself was the author. (Incidentally, J.S.C. quotes a 1773 Essai sur

\footnotetext{
3 "Una pieza tan irregular, dictada sólo por el ingenio y sin los auxilios que presta el arte" (Moratín 1867-1868:179).

4 “Tales obras, aunque contengan pedazos excelentes, servirán solo de perpetuar la corrupcion del gusto; y si llega á admitirse la máxîma de que el ingenio no debe sujetarse á los preceptos científicos, y que no es lícito exâminar á aquellos grandes hombres, discípulos de la naturaleza, fecundos é incultos como el original que imitaron: no hay medio, esta opinion acreditada una vez, será la ruina de las artes" (Celenio [Moratín] 1798:n.p.).
} 


\section{A. L. Pujante}

l'art dramatique "by a famous writer," who proclaimed that Corneille "[...] has been and will be the favourite of great souls for all ages"). ${ }^{5}$

Romo was clearly at fault for appropriating someone else's article and ideas without quoting his sources, to the extent of signing it as his own and thus leading critics like Par to believe it was his. To his credit he contributed to the reception of Shakespeare in Spain in sharing those ideas and taking sides in favour of Shakespeare, to the point of even manipulating Moratín's opinion to his own advantage.

3 In the section on Shakespeare reception in the Spanish Romantic period, Alfonso Par presents the "venerable figure of Antonio Bergnes", a Catalan professor of Greek, critic and translator, who "dealt with Shakespeare in his journal El Museo de Familias" (1935:331-332). Par discusses two unsigned articles that he attributes to Bergnes: "Shakspeare" (1839), and "Comparación entre las literaturas de los diversos países del globo" (1840). In "Shakspeare", on which I shall concentrate here, Par praises the author's interpretation of the character of Hamlet and, among other things, mentions Bergnes' complaint that the Spaniards did not manage to represent the episodes of the Reconquista as Shakespeare did in his history plays. Par concludes that Bergnes' is a "notable" study, revealing "a good knowledge of the English commentators of the time, as well as personal critical independence." ${ }^{\prime 6}$

Par attributed the Shakespeare article to Bergnes -as he did the 1840 article- because he knew that he was the editor of El Museo de Familias, thus taking for granted that, since the 18th century, most of the articles in such relatively popular journals were the work of the editors themselves, who often published them anonymously. Elsewhere the journal acknowledged a collaboration, thanked the collaborator by name, and invited more such publications (1839:II.302). Nevertheless, "Shakspeare" was not an original article by Bergnes, as Par must have thought, but an almost literal translation of "Essai biographique et littéraire sur Shakspeare" (1838)

\footnotetext{
5 The writer in question, not named by J.S.C., was Louis-Sébastien Mercier. The original French quotation reads: "a été \& sera dans tous les tem[p]s le favori des grandes âmes" (Mercier 1773:220).

6 "Buen conocimiento de los comentaristas ingleses de su tiempo, al par que independencia crítica personal" (Par 1935:335).
} 
by the writer, politician and professor Albert-François Villemain (1791-1870), which was later variously reprinted. The following parallel quotations will suffice to show the real origin of the article.

French original

Shakspeare (William), l'homme de génie du théâtre anglais, naquit le 23 avril 1564, à Stratford sur Avon, dans le comté de Warwick. On sait fort peu de chose sur les premières années, et sur la vie de cet homme si célèbre; et malgré les recherches minutieuses de l'érudition biographique, excitée par l'intérêt d'un si grand nom, et par l'amour-propre national, les Anglais ne connaissent guère de lui que ses ouvrages. [...] Ben-Johnson, Fletcher et Beaumont, n'avaient ni plus ni moins d'art; mais souvent cheux eux cette excessive liberté 'amenait que des combinaisons vulgaires; et presque toujours ils manquent d'éloquence. Dans Shakespeare, les scènes brusques et sans liaison offrent quelque chose de terrible et d'inattendu. [...] La soif inextinguible de l'or, la cruauté avide et basse, l'âpreté d'une haine ulcérée par les affronts y sont tracées avec une incomparable énergie, et l'un de ces caractères de femme si gracieux sous la plume de Shakspeare répand dans ce même ouvrage, au milieu d'une intrigue romanesque, le charme de la passion. $[\ldots]$
Spanish text

Guillermo Shakespeare, á quien podemos llamar el rey del teatro inglés, nació el 23 de abril de 1564, en Stratford, a orillas del Avon, en el condado de Warwick. Se tienen muy pocas noticias de los primeros años de la vida de este hombre tan célebre; y á pesar de las minuciosas investigaciones de la erudicion biográfica, provocada por el interés que despierta un nombre tan ilustre, los Ingleses no conocen de él mas que sus obras. Ben Johnson, Fletcher y Beaumont no conocían ni más ni menos el arte; pero en ellos con frecuencia esta escesiva libertad no producia mas que combinaciones vulgares, y además carecian siempre de elocuencia. En Shakespeare hasta las escenas mas bruscas y sin enlace ofrecen algo de terrible e inesperado. Vense trazados en él con una enerjia inimitable la sed inestinguible del oro, la crueldad mas codiciosa y rastrera, la aspereza de un odio enconado por las afrentas; al mismo tiempo que uno de esos caracteres de mujer, tan graciosos bajo la pluma de Shakespeare, derrama en esta misma obra, en medio de una trama anovelada, el encanto de la pasión.

Like Romo, the editor here made some changes and adjustments. He did not translate a sentence in the original to the effect that Shakespeare depicts both the most tragic and the most 


\section{A. L. Pujante}

graceful in his characters, which he probably skipped through oversight. He also left untranslated the last paragraph and bibliographical notes in the original -devoted to Shakespeare scholarship and editions- presumably because it would have been excessive for a popular journal. Perhaps for a similar reason he omitted a reference to two characters in Voltaire's Zaïre and to the style of the poet Du Bellay. However, his other changes were in all probability effected to erase all traces of the original publication. Thus all French references were de-Frenchified: in the Spanish text "notre Corneille" and "notre Molière" become simply "Corneille" and "Molière"; "notre tragédie française", "la tragedia francesa"; "[le] grossier théâtre que nous avions", "[el] grosero teatro que tenían los Franceses".

But surely the most significant change also involves what is one of the most interesting observations in Villemain. As John Pemble puts it, Villemain, who had Shakespeare's history plays in mind, had complained that the French had no Shakespeare, no "literary genius who had nurtured a national memory and set hearts beating faster with a sense of purpose, possibility, and destiny" (2005:18). Therefore, in Villemain's words, they lacked a playwright capable of staging, giving his words a savage energy, "the revengeful deeds of Louis XI, the crimes of the palace of Charles IX, the audacity of the Guises, and the furious atrocities of the League," with the result that the French had no taste for their manners, "nor, above all, any portion of the enthusiasm of national patriotism" (cit. Pemble 2005:18). Faced with these French references, the Spanish editor replaced them with two from Spanish history ("the revengeful deeds of Pedro el Cruel, the wars against the Moors").

As far as Bergnes' appropriation is concerned, it had been customary for many such periodicals since the 18th century to incorporate all kinds of articles, notes and news from various foreign newspapers, particularly French (Saiz 1983:143), which were then translated and/or adapted by the Spanish editor and published anonymously without citation of the sources. On the other hand, there were others, like the Espiritu de los mejores diarios que se publican en Europa, whose editor, Cristóbal Cladera, controlled the quality and prestige of his newspaper, quoted his sources of information and offered a detailed description of the reviews, newspapers, articles and books he received (Saiz 1983:191). On the whole, 
however, it would seem that a number of editors and readers at the time did not pay much attention or attach much importance to such matters, so that an anonymous article could easily be attributed to the editor of the publication. This state of affairs also seems to have continued down to Alfonso Par's time, as we have seen, and may have encouraged other appropriations and/or wrongful uses in Shakespeare reception in Spain which we have not yet detected.

4 Discussing the reception of Shakespeare in Spain at the end of the 18th century, Alfonso Par (1935:105-106) mentions "Reflexiones sobre el teatro inglés," an essay by Joseph Calderón de la Barca, published in a 1797 issue of the Memorial Literario. Its author, whom Par refers to as the editor of the journal, expresses a rather critical view of Shakespeare. The source for all this information is Menéndez Pelayo's Historia de las ideas estéticas en España, whose comments on Joseph Calderón and his essay Par follows closely. However, Menéndez Pelayo has been corrected (Urzainqui 1990:508) to the effect that Calderón was not the editor of the journal but a very frequent collaborator. Par, therefore, follows his source in this mistake, as well as in the fact, not mentioned by Menéndez Pelayo, that the essay was published anonymously. However, neither the mistake nor the omission questions Calderón's authorship. Both critics mention that the author of the essay refers in a footnote to a previous article ("Carta apologética en defensa de Lope de Vega y otros poetas cómicos españoles"), published a year earlier in the same journal and signed J.M.C.B. (i.e. Joseph María Calderón de la Barca), in which Shakespeare is also criticised, thus making his hand in the 1797 essay highly probable, if not certain beyond doubt.

Commenting on the content of "Reflexiones sobre el teatro inglés," Par thinks that Joseph Calderón did not understand Shakespeare, and quotes what for him are surprisingly derogatory sentences revealing "aesthetic blindness." However, this Spanish essay was for the most part an almost literal rendering of Voltaire's 18th letter ("Sur la tragédie") and 19th letter ("Sur la comédie"), included in his Lettres philosophiques (1734). Let us look at these statements in the Spanish text set against the French original ("Sur la tragédie"): 
Voltaire

Il [Shakespeare] avait un génie plein de force et de fécondité, de naturel et de sublime, sans la moindre étincelle de bon goût. [...] Ja vais vous dire une chose hasardée, mais vraie: c'est que le mérite de cet Auteur a perdu le théâtre anglais; il y a de si belles scènes, des morceaux si grands et si terribles répandus dans ses Farces monstrueuses qu'on appelle Tragédies, que ces pièces ont toujours été jouées avec un grand succès. [...] La plupart des idées bizarres et gigantesques de cet auteur ont acquis au bout de deux cents ans le droit de passer pour sublimes. [...] Vous savez que dans la tragédie du More de Venise, pièce très touchante, un mari étrangle sa femme sur le théâtre, et quand la pauvre femme est étranglée, elle s'écrie qu'elle meurt très injustement. Vous n'ignorez pas que dans Hamlet des fossoyeurs creusent une fosse en buvant, en chantant des vaudevilles, et en faisant sur les têtes des morts qu'ils rencontrent des plaisanteries convenables à gens de leur métier. Mais ce qui vous surprendra, c'est qu'on a imité ces sottises. [...] On a laissé dans le Jules César de Shakespeare les plaisanteries des cordonniers et des savetiers romains introduits sur la scène avec Brutus et Cassius. [...] Le génie poétique des Anglais ressemble jusqu'à présent à un arbre touffu planté par la
Spanish text

[Shakespear] era hombre de un ingenio vehemente $\mathrm{y}$ fecundo, harto natural y sublime; pero sin la menor chispa de buen gusto [...] Me atrevo á decir que el mérito de este autor perdió el teatro Ingles: pues, conteniendo sus farsas monstruosas (que por mal nombre llaman tragedias) escenas admirables y acciones terribles, las tales piezas se han representado con sumo aplauso [...] Las ideas extravagantes y gigantéas de este autor han adquirido al cabo de 150 años derecho de pasar por sublimes. Bien sabido es que en la tragedia el Moro de Venecia, pieza á la verdad interesante, un marido ahoga a su mujer en el teatro, y después de muerta exclama que muere injustamente. En la tragedia Ham[l]et los mullidores estaban en una fosa bebiendo tragos, cantando xacaras y chuleándose con las calaveras que hallan en un lenguaje propio de su oficio; pero lo que me admira todavía mas es que hayan imitado tamañas necedades [...] Pero han dexado en Julio Cesar del mismo Shakespear chanzas pesadas de sastres y zapateros Romanos, que alternan en la escena de Casio y Bruto [...] El ingenio poético de esta nación es semejante a un arbol silvestre muy copado, que brota hácia todas partes con si suma fuerza. Muere si alguno intenta oprimir su naturaleza, y podarle como los árboles del retiro. 
nature, jetant au hasard mille rameaux, et croissant inégalement et avec force; il meurt, vous voulez forcer sa nature et le tailler en arbre des jardins de Marly.

The translation is virtually literal. Menéndez Pelayo -whom Par follows and paraphrases- observes that Joseph Calderón "repeated Voltaire's jokes" on the gravediggers in Hamlet, and he praises Calderón's "happy comparison" between the poetic genius of England and a wild leafy tree branching out forcefully in all directions (1886:III.2.157). However, as can be seen in the above quotations, Menéndez Pelayo does not seem to have noticed the literalness of Calderón's "repetition" of Voltaire's jokes, or to have realised that the "happy comparison" had previously been expressed by Voltaire.

Clearly, Par repeats Menéndez Pelayo's error. But there is more. As can also be seen at the end of the Spanish text in the above quotation, the wild tree to which the poetic genius of England is compared and which would die if pruned is like the trees in the Madrid gardens of the Retiro -these gardens having, therefore, replaced those of the French Marly palace in Voltaire. But in his quotation Menéndez Pelayo added "or of Versailles" ("ó de Versalles"). Why did he place this French reference after the Spanish one as an alternative? Was it because, after all, he knew the French original and therefore Voltaire's reference to Marly -the palace to which King Louis XIV wanted to move to get away from Versailles?

As it happens, Menéndez Pelayo had referred to Voltaire's 18th letter in the previous volume to the one in which he discussed the 1797 article: "[Voltaire] had discovered a treasure that he failed to exploit: Shakespeare's drama. How much amazement must have been produced by those Lettres anglaises, in which Hamlet's soliloquy appeared in translation for the first time!" ${ }^{\prime 7}$ And three pages later he added: "in the Lettres anglaises [Voltaire] had called Shakespeare 'a genius full of force, fecundity and sublimity, although without the least knowledge of the rules', and the tragedy of The Moor of Venice 'a

7 "[Voltaire] había descubierto un tesoro que no acertó á explotar: el teatro de Shakespeare. ¡Qué asombro debieron de producir aquellas Cartas sobre los ingleses, donde por primera vez apareció traducido el monólogo de Hamlet!" (1886:III.1.58). 


\section{A. L. Pujante}

very moving play'. $^{\prime \prime}{ }^{8}$ It should be clear that he had read Voltaire's letter, from which he cites in translation, albeit carelessly. ${ }^{9}$ But then, why did he praise Joseph Calderón and not Voltaire for the "happy comparison" between the poetic genius of England and a wild leafy tree? Perhaps, since he quoted Calderón's text and the comparison inaccurately - probably by heart or from badly taken notes, like his references to the Lettres anglaises- he did not realise the nature and origin of the 1797 article, or he did realise and preferred not to go into it.

Be that as it may, we are not dealing here with appropriations of sentences or of a single comparison, but of a significant portion of the 18th letter, so that the French writer's observations were consciously passed off as a Spanish author's "Reflexiones." In the first place, Joseph Calderón's translation skips Voltaire's rendering of the "to be or not to be speech" included in the letter, so that when Voltaire says that he has ventured ("hasardé") to translate it, the Spanish editor retains this, but leaps ahead to a speech by Dryden also translated by Voltaire which comes next and says he has tried ("intentado") to translate Dryden -even if he renders only the first four lines. The omission of the Shakespearean soliloquy clearly shows his purpose. Voltaire's translation of it in French rhymed couplets is deliberately poetic and free -he expressly curses the literal translators for weakening the sense by rendering it word for word (1964:107). It reads, therefore, rather differently from the blank verse speech in Shakespeare, so that translating the French instead of the English original would leave the article open to suspicion or clearly reveal its real origin.

Other than that, Joseph Calderón did sign most of his collaborations in the Memorial Literario, either as J.M.C.B or as "Don Joseph Maria Calderon de la Barca. ${ }^{\prime 10}$ Besides, this journal did not

\footnotetext{
8 "En las Cartas sobre los Ingleses [Voltaire] había llamado á Shakespeare 'genio lleno de fuerza, de fecundidad y de sublimidad, aunque sin el menor conocimiento de las reglas', y á la tragedia del Moro de Venecia, 'pieza muy patética'”' (1886:III.1.61).

${ }^{9}$ This can be seen by comparing his citations with the French original, which is quoted above in parallel with Calderón's text.

${ }^{10}$ See, for example, the December 1796 issue of the periodical, "Carta del célebre físico Deslandes sobre la pesca de los salmones [...]," por J.M.C.B.; "J.M.C.B.: Traductor al castellano de "Reflexiones filosóficas sobre el origen de las lenguas [...]." Or, in the table of contents: "Discurso histórico sobre el origen y progreso de la ciencia Musica," by Don Joseph Maria Calderon de la Barca (137-171).
} 
always omit the name of the authors. ${ }^{11}$ It would seem, therefore, that if Joseph Calderón published the "Reflexiones" anonymously when otherwise he usually signed his work, it was because he wanted to avoid the accusation of wrongfully using an essay by none other than Voltaire, and this would also explain why he manipulated the original so that the resulting Spanish text would be less noticeable or suspect. But I think there is a yet more decisive reason involved.

In the 18th century both governmental and ecclesiastical censorship controlled publication in Spain. The latter (i.e. the Inquisition) was the more active. Voltaire, branded the most impious of all French philosophers, was one of its most distinguished victims. His Lettres philosophiques was banned in 1756, and in 1762 all his works were outlawed (Lafarga 1975:5). There were occasional cases of leniency, but they were exceptions that confirmed the rule, and by the end of the century the situation had not changed. In the circumstances, it is understandable that the publication in Spanish of an essay by Voltaire, even if it was not "impious" and was then over sixty years old, would be considered a dangerous initiative, and that, if published, anonymity and textual manipulation would be called for. If we accept this, it would seem that, since Joseph Calderón did not claim personal authorship, the purpose of publication was to spread Voltaire's ideas without risking censorship.

5 There can be no doubt that translations of foreign critical texts on Shakespeare are also an important part of his reception. Alfonso Par, for one, discusses the Spanish rendering (1798-99) of Hugh Blair's Lectures on Rhetoric and Belles Lettres as making accessible to the Spanish readership a number of important observations on Shakespeare which otherwise would have remained unknown to them (1935:I.123-126). Likewise, the translations dealt with in the present article were useful in providing information and ideas on Shakespeare, and in contributing to the debate about him, not so much with Bergnes in 1840 , when Shakespeare was already viewed favourably in Spain, but in the two previous cases, when the issue was still open to debate. As the purpose of this article was not

\footnotetext{
${ }^{11}$ For instance, in the table of contents of the 1806 issue, we can read: "Artículo escrito en alemán por el Doctor Collenbuch" or "Extracto de una memoria leída [...] por los Sres. Fourcroy y Vauquelin" (433).
} 


\section{A. L. Pujante}

to discuss these instances as judicial cases, the focus has not been on condemning them as plagiarism or wrongful use of their originals. Instead, the aim here is to correct erroneous information and thus contribute to our knowledge of the Spanish reception of Shakespeare, while agreeing with Par on its importance.

Having said this, I hope I may be allowed to speculate about a historical aspect involved in the publication of the first two translations. Both were published as contemporary articles, but Joseph Calderón's original had appeared over sixty years before, and Romo's nearly fifty. The two renderings came out around the turn of the century, when Neoclassicism was still alive in Spain and most Spanish writings on Shakespeare were still unfavourable to him. But in France Shakespeare was being received at this time more openly than before, and Voltaire-like attitudes to him would soon be a thing of the past. In the case of Calderón, if his aim was to spread Voltaire's ideas -though censorship made it impossible to publish a Voltairean original in 1797- it would have been more to the point to bring out his unsigned text as the translation of an anonymous French original of 1734. As for the Romo appropriation of 1806, whose publication as a Spanish original provoked an angry response in a Spanish reader of neoclassical sympathies, he might have defended Shakespeare better if, instead of proposing the parallel as his own, he had presented it as the rendering of a French original of almost half a century earlier, in which France's national playwright was not even then preferred to Shakespeare; at least, his reader's reaction would have been more pondered -or there would have been no reaction at all.

\section{References}

Anon. 1760. "Parallèle Entre Shakespear \& Corneille traduit de 1'Anglois." Journal Encyclopédique Octobre: 100-105.

Anon. 1797 (marzo). "Reflexiones sobre el teatro Ingles." Memorial Literario: 352-360.

Anon. 1839. "Shakspeare." El Museo de Familias II: 381-389.

C[alderón], J.S. 1806 (30 Marzo). "Reflexîones acerca del paralelo entre Shakespeare y Corneille, inserto en el Núm. $5^{\circ}$ de este Periódico." Memorial Literario: 385-394.

Calvo, Clara 2002. "Románticos españoles y tragedia inglesa: El fracaso del Macbeth de José García de Villalta." Eds. F. Lafarga, C. Palacios \& A. 
Saura. Neoclásicos y Románticos ante la Traducción. Murcia: Universidad de Murcia: 59-72.

Calvo, Clara 2006. "De-foreignising Shakespeare: Othello in Romantic Spain." Ed. J.M. González. Spanish Studies in Shakespeare and his Contemporaries. Newark: University of Delaware Press: 117-119.

Calvo, Clara 2008. "Shakespeare, Napoleon and Juan de Grimaldi: Cultural Politics and French Troops in Spain." Eds. D. Delabastita, J. De Vos and P. Franssen. Shakespeare and European Politics. Newark: University of Delaware Press: 109-123.

Celenio, Inarco [Fernández de Moratín, L.] 1798. Hamlet. Tragedia de Guillermo Shakespeare. Madrid: Villalpando.

Deacon, Philip 1996. "La traducción de Hamlet de Leandro Fernández de Moratín." Eds. A.L. Pujante \& K. Gregor. Teatro clásico en traducción: Texto, representación, recepción. Murcia: Universidad de Murcia: 299-308.

Fernández de Moratín, Leandro 1867-1868. Obras póstumas de D. Leandro Fernández de Moratín. Madrid: Rivadeneyra.

Gregor, Keith 2002. "From Tragedy to Sainete: Othello on the Early Nineteenth-Century Spanish Stage." Eds. J.M. González and H. Klein. Shakespeare and Spain. Lewiston: The Edwin Mellen Press: 322-341.

Gregor, Keith 2003. "Shakespeare as a Character on the Spanish Stage: A Metaphysics of Bardic Presence." Eds. A.L. Pujante and T. Hoenselaars. Four Hundred Years of Shakespeare in Europe. Newark and London: Associated University Presses: 43-53.

Gregor, Keith 2010. Shakespeare in the Spanish Theatre. 1772 to the Present. London and New York: Continuum.

Juliá Martínez, Eeduardo 1918. Shakespeare en España. Traducciones, imitaciones e influencia de las obras de Shakespeare en la literatura española. Madrid: Tip. de la Revista de Archivos, Bibliotecas y Museos.

Jusserand, Jean Jules 1889. Shakespeare in France under the Ancien Régime. London: T.F. Unwin.

Kerson, Pilar R. 1989a. “Leandro Fernández de Moratín: primer traductor de Shakespeare en castellano. Antecedentes y preliminares a su versión de Hamlet." Dieciocho 12/1: 45-65.

Kerson, Pilar R. 1989b. "Moratín y Shakespeare: un ilustrado español ante el dramaturgo inglés." Ed. S. Neumeister. Actas del IX Congreso de la Asociación Internacional de Hispanistas (1986). Frankfurt a. Main: Vervuert Verlag: $75^{-83}$.

Lafarga Maduell, Francisco 1975. Voltaire en España. Difusión y traducción de sus obras hasta 1835. Barcelona: Universidad de Barcelona. 
López, Daniel 1883. "Shakespeare en España." La ilustración Española y Americana 27: no. 25, 10-11; no. 26, 22-23; no. 27, 46; no. 28, 58-59; no. 29, 74 .

López Román, Blanca 1988. "Transformaciones neoclásicas del Macbeth shakespeariano." Revista Canaria de Estudios Ingleses 17: 281-294.

López Román, Blanca 1989. "Procesos de transformación de Shakespeare en la traducción de Hamlet de Moratín." Barcelona English Language and Literature Studies 1: 117-123.

López Román, Blanca 1993. "Biografías españolas de Shakespeare." Ed. J.M. González Shakespeare en España. Crítica, traducciones y representaciones. Zaragoza: Pórtico.

Menéndez Pelayo, Marcelino 1886. Historia de las ideas estéticas en España (Tomo III, vols. I \& II). Madrid: Pérez Dubrull.

Mercier, Louis Sébastien 1773. Du théâtre, ou Nouvel essai sur l'art dramatique. Amsterdam: E. Van Harrevelt.

Moro, Pablo 1996. "Hamleto, rey de Dinamarca: un Shakespeare 'francés' a la española." Eds. A.L. Pujante \& K. Gregor. Teatro clásico en traducción: Texto, representación, recepción. Murcia: Universidad de Murcia: 331-338.

Par, Alfonso 1935. Shakespeare en la literatura española. Madrid/Barcelona: Victoriano Suárez/Biblioteca Balmes.

Pemble, John 2005. Shakespeare Goes to Paris. London and New York: Hambledon and London.

Pujante, Ángel-Luis 1999. "Spanish and European Shakespeares: Some Considerations." Folio 6: 17-38.

Pujante, Ángel-Luis ed. 2001a. El manuscrito shakespeariano de Manuel Herrera Bustamante. Santander: Sociedad Menéndez Pelayo.

Pujante, Ángel-Luis 2001b. "Shakespeare or/and..? The Spanish Counterpart in the 18th and 19th Centuries." Eds. B. Sokolova and E. Pancheva. Renaissance Refractions. Essays in Honour of Alexander Shurbanov. Sofia: St. Kliment Ohridski University Press: 157-169.

Pujante, Ángel-Luis 2005. "Limando asperezas: Juan Andrés y Shakespeare." Eds. Ricardo Escavy et al. Amica Verba. In honorem Prof. Antonio Roldán Pérez. Tomo 2. Murcia: Universidad de Murcia: 859-871.

Pujante, Ángel-Luis 2006. "Manuel Herrera on Shakespeare: A New Spanish Manuscript from the Romantic Period." Ed. J.M. González. Spanish Studies in Shakespeare and his Contemporaries. Newark: University of Delaware Press: 21-42.

Pujante, Ángel-Luis 2008. "Fame at Last: The Recent Première of Moratín's Hamlet (1798)." Eds. C. Dente and S. Soncini. Crossing Time and Space. 
Shakespeare Translations in Present-Day Europe. Pisa: Edizioni Plus. Pisa University Press: 142-152.

Pujante, Ángel-Luis \& Laura Campillo, eds. 2007. Shakespere en España. Textos 1764-1916. Granada \& Murcia: Universidad de Granada \& Universidad de Murcia.

Pujante, Ángel-Luis and Keith Gregor 2005. "The Four Neoclassical Spanish Hamlets: Assimilation and Revision." Sederi 15: 129-141.

Pujante, Ángel-Luis and Keith Gregor 2008. "Conservatism and Liberalism in the Four Spanish Renderings of Ducis's Hamlet." Eds. D. Delabastita, J. De Vos and P. Franssen. Shakespeare and European Politics. Newark: University of Delaware Press: 304-317.

Romo, G. 1806. "Paralelo entre Shakespeare y Corneille." Memorial Literario 20 Febrero: 221-228.

Ruppert y Ujaravi, Ricardo 1920. Shakespeare en España. Traducciones, imitaciones e influencia de las obras de Shakespeare en la literatura española. Madrid: Tipografía de la Revista de Archivos, Bibliotecas y Museos.

Sáiz, Ma Dolores 1983. Historia del periodismo en España. 1: Los orígenes. El siglo XVIII. Madrid: Alianza.

Urzainqui, Inmaculada 1990. "Los redactores del Memorial Literario (17841808)." Estudios de Historia Social 1-2: 501-516.

Verdaguer, Isabel 2004. "Shakespeare's 'Poem Unlimited' in EighteenthCentury Spain." Eds. R. C. Homem and T. Hoenselaars. Translating Shakespeare for the Twenty-First Century. Amsterdam \& New York: Rodopi: 129-143.

Villemain, Abel François 1838. Essai biographique et littéraire sur Shakspeare. Paris: Belin-Mandar.

Voltaire 1964 (1734). Lettres philosophiques ou Lettres anglaises. Paris: Garnier.

How to cite this article:

Pujante, Ángel-Luis. "The French Influence on Early Shakespeare Reception in

Spain: Three Cases of Unacknowledged Sources." SEDERI 20 (2010): 103-119.

Author's contact: apujante@um.es

Submission: 30/10/2009

Acceptance: 26/12/2009 